\title{
Avaliação do extrato etanólico de casca de Punica granatum (romã) na diminuição da replicação viral do BoHV-1 Colorado em embriões murinos experimentalmente infectados**
}

\author{
Evaluation of ethanol extract of Punica granatum (Pomegranate) peel decrease in \\ viral replication of BoHV-1 in Colorado murine embryos experimentally infected
}

\author{
Eduardo Gimenes Palazzi ${ }^{1,2 *}$, Edviges Maristela Pituco², Elisabete Jose Vicente ${ }^{2}$, Daiane Hansen ${ }^{1}$, \\ Joana D'Arc Felicio', Michele dos Santos Lima', Adriana Hellmeister de Campos Nogueira', \\ Eliane De Stephano', Liria Hiromi Okuda ', Magali D ‘Angelo' ${ }^{1 \dagger}$
}

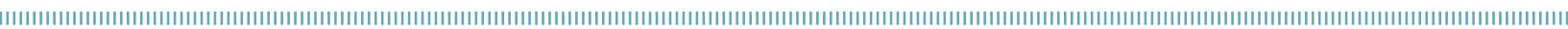

RESUMO: O objetivo do trabalho foi avaliar a diminuição da replicação viral (BoHV-1 Colorado) em embriôes murinos após tratamento do extrato etanólico da casca de Punica granatum (EEPg). Camundongos fêmeas Swiss com idade entre 6 e 8 semanas foram superovuladas com 0,2 $\mathrm{mL}$ a 5 UI de hormônios (eCG e hCG), e acasaladas com machos da mesma idade. Após 18 horas, as fêmeas sofreram eutanásia em câmara de $\mathrm{CO}_{2}$ e, através de abertura no peritônio, os zigotos foram coletados e lavados com solução de pronase $0,5 \%$. Os zigotos foram divididos em quatro grupos: $\mathrm{G}_{1}$ (controle), $\mathrm{G}_{2}$ (expostos aos vírus BoHV-1 Colorado a $10^{8} \mathrm{TCID}_{50} / \mathrm{mL}$ ), $\mathrm{G}_{3}$ (expostos ao EEPg) e $\mathrm{G}_{4}$ (expostos aos vírus e ao EEPg). Os grupos foram mantidos a $37,5^{\circ} \mathrm{C}$ em meio TCM199 $(100 \mu \mathrm{L})$ com $10 \%$ de soro fetal bovino em estufa a $5 \%$ de $\mathrm{CO}_{2}$ e $95 \%$ de umidade. Após $24 \mathrm{~h}$, analisamos a taxa de clivagem (teste exato de Fisher; $\mathrm{p}<0,05$ ), a morfologia (por microscopia óptica), a nested-PCR e a titulação dos embrióes em cocultura com células MDBK após mais $72 \mathrm{~h}$ do tratamento (teste de Mann-Whitney; $\mathrm{p}<0,05$ ) e microscopia eletrônica de transmissão (ME). Os embrióes murinos tratados com EEPg apresentaram resultados satisfatórios: sem alteraçóes morfológicas, taxa de clivagem semelhante ao controle e, apesar da detecção da presença do vírus pela nested-PCR e ME, houve diminuição do título viral após tratamentos com esse extrato, o que sugere interferência desse tratamento no ciclo viral do BoHV-1 Colorado sem alterar o desenvolvimento dos embrióes.

PALAVRAS-CHAVE: extrato etanólico; romã; embriôes murinos; BoHV-1; diminuição da replicação viral.

\begin{abstract}
The aim of this study was to evaluate the reduction of viral replication (Colorado BoHV-1) in murine embryos after the treatment of ethanol extract of Punica granatum peel (PgEE). Swiss female mice aged 6 to 8 weeks were superovulated with $0.2 \mathrm{~mL}$ of the $5 \mathrm{UI}$ hormones (eCG and hCG) and mated with males of the same age. After 18 hours, the females were euthanized in a $\mathrm{CO}_{2}$ chamber, and through the opening in the peritoneum, zygotes were collected and washed with $0.5 \%$ pronase solution. The zygotes were divided into four groups: $G_{1}$ (control), $G_{2}$ (exposed to the virus Colorado BoHV -1 to $10^{8} \mathrm{TCID}_{50} / \mathrm{mL}$ ), $\mathrm{G}_{3}$ (exposed to PgEE) and $\mathrm{G}_{4}$ (exposed to the virus and to PgEE). The groups were maintained at $37.5^{\circ} \mathrm{C}$ in TCM199 $(100 \mathrm{~mL})$ with $10 \%$ fetal bovine serum in an incubator at $5 \% \mathrm{CO}_{2}$ and $95 \%$ humidity. After $24 \mathrm{~h}$, we analyzed the cleavage rate (Fisher's exact test; $\mathrm{p}<0.05$ ), the morphology (by light microscopy), the nestedPCR and the titration of embryos in co-culture with MDBK cells after over $72 \mathrm{~h}$ of treatment (Mann-Whitney test; $\mathrm{p}<0.05)$ and transmission electron microscopy (TEM). The murine embryos treated with PgEE showed satisfactory results: no morphological changes, cleavage rate similar to controls, despite the detection of the presence of virus by nested PCR and TEM, there was a decrease of the viral titer after the treatment with this extract, which suggests interference of this treatment in the viral cycle BoHV-1 Colorado without altering the embryo development.
\end{abstract}

KEYWORDS: ethanol extract; pomegranate; murine embryos; BoHV-1; reduction of viral replication.

\footnotetext{
'Instituto Biológico, Laboratório de Viroses de Bovídeos - São Paulo (SP). Brasil.

${ }^{2}$ Instituto de Ciências Biomédicas III, Programa de Pós Graduação Interunidades em Biotecnologia, USP - São Paulo (SP), Brasil.

*Autor correspondente: palazzidu@usp.br

tIn memorian

Recebido em: 24/09/2013. Aceito em: 20/03/2015

**Parte da tese de doutoramento do primeiro autor realizado junto ao Programa de Pós-Graduação Interunidades em Biotecnologia da Universidade de São Paulo.
} 


\section{INTRODUÇÃO}

A lavagem sequencial (LS) e o tratamento de tripsina (TT), tratamentos sugeridos e estabelecidos pela International Embryo Transfer Society (IETS) cuja finalidade é tentar impedir o deslocamento de patógenos junto aos embrióes, durante a produção in vitro (PIV), até o momento da transferência embrionária em animais de produção não possuem eficácia. Inúmeros trabalhos demonstram a ineficiência desses tratamentos (SINGH et al., 1982; Stringfellow et al., 1990; Palazzi, 2010), pois são limitados ao meio externo dos embrióes (STringfellow; Givens, 2000), náo tendo efeito aos patógenos que já se encontram dentro das células, segundo inúmeros ensaios in vitro (PaLAzzi, 2010). Dentre os diversos patógenos com relevância, os herpesvírus bovinos configuram entre os agentes com distribuição mundial e importância econômica significativa (CoLODEL et al., 2002; KUnRATH et al., 2004). São inúmeras as doenças causadas pelos herpesvírus: rinotraqueíte infecciosa bovina (IBR), conjuntivite, vulvovaginite pustular infecciosa (IPV), balanopostite pustular infecciosa (IPB), reabsorção embrionária, aborto, infertilidade temporária, nascimento de animais fracos e infecçóes sistêmicas que podem resultar em meningoencefalite (CERQueIra et al., 2000; VIeIra et al., 2003). Não há, até o momento, antivirais relacionados às células reprodutivas para serem usados em Centrais de Fertilização. Por isso, o objetivo deste trabalho foi o de avaliar a eficiência do extrato etanólico de Punica granatum (EEPg), in vitro, em relação à diminuição da replicaçáo viral do BoHV-1 Colorado em embrióes murinos pelas seguintes análises: morfologia, taxa de clivagem, nested PCR (n-PCR), cocultivo em células MDBK, titulação viral e microscopia eletrônica de transmissão (MET).

\section{MATERIAL E MÉTODOS}

\section{Vírus}

Foi utilizado o herpesvírus bovino tipo-1 (BoHV-1), estirpe Colorado, $7^{\text {a }}$ passagem em células MDBK, com título de $10^{8}$ TCID $50 / \mathrm{mL}$ mantida em meio Eagle MEM sem soro fetal bovino à $-80^{\circ} \mathrm{C}$. A amostra foi cedida, gentilmente, pelo Prof. Paulo Michel Roehe da Universidade Federal do Rio Grande do Sul, Instituto de Biociências, Departamento de Microbiologia.

\section{Titulação dos vírus}

Volumes de $0,1 \mathrm{~mL}$ contendo $3 \times 10^{4}$ (30 mil) células foram distribuídos em cada cavidade de placas de microtitulação com 96 poços. As placas foram incubadas a 37 a $38^{\circ} \mathrm{C}$ em estufa com $5 \%$ de $\mathrm{CO}_{2}$ e, após 24 horas, lavadas com solução salina de Hanks. Os monoestratos foram inoculados com $0,1 \mathrm{~mL}$ de diluiçóes de base 10 variando de $10^{-1}$ a $10^{-8}$ das amostras dos sobrenadantes das culturas e do lisado celular. As placas foram novamente incubadas nas condiçóes já descritas e examinadas após 24 e 48 horas para a verificação da ocorrência de efeito citopático (CPE). Os títulos foram calculados em dose infectante por cultura de tecido $50 \%\left(\mathrm{TCID}_{50} / \mathrm{mL}\right)$ expressa em logaritmo decimal (Reed; Muench, 1938).

\section{Métodos de detecção do BoHV-1 em cultivo de células}

As amostras foram inoculadas em monoestratos de células MDBK e, após $48 \mathrm{~h}$ de incubação a $38^{\circ} \mathrm{C}$ em estufa com $5 \%$ de $\mathrm{CO}_{2}$ e $95 \%$ de umidade, foi verificada a presença ou não de CPE. O BoHV-1 Colorado induz um CPE focal, com arredondamento das células e subsequente lise (PALAzZi, 2010).

\section{Punica granatum}

Arbusto ramoso de até $3 \mathrm{~m}$ de altura, com folhas simples, cartáceas, dispostas em grupo de 2 ou 3 , de 4 a $8 \mathrm{~cm}$ de comprimento. Flores solitárias constituídas de corola vermelho-alaranjada e um cálice esverdeado, duro e coriáceo. Frutos do tipo baga, globoides, medindo até $12 \mathrm{~cm}$, com numerosas sementes envolvidas por arilo róseo, cheio de um líquido adocicado. Provavelmente originária da Ásia e espalhada em toda a regiâo do Mediterrâneo e cultivada em quase todo o mundo, inclusive no Brasil, onde recebe o nome de romã (Lorenzi; Matos, 2002). Seus frutos são comestíveis, sendo o pericarpo, que é a parte externa do fruto, usado para tratamento de inflamaçóes na boca e na garganta. A análise fitoquímica dessa planta registra, além dos alcaloides, a presença de até $28 \%$ de taninos nas cascas do caule e dos frutos e, em menor quantidade, nas folhas; na semente foi registrada $7 \%$ de um óleo fixo, que entre seus ácidos graxos está principalmente o ácido punícico (Sousa et al., 1991). Os ensaios farmacológicos realizados com extratos do pericarpo mostraram atividade contra bactérias patogênicas e inibição do crescimento de tumores experimentais, enquanto os taninos do pericarpo se mostraram ativos contra o vírus HVS-2 do herpes genital, inibindo sua replicação e bloqueando, em cultura de células, a adsorção nas células já testadas (Lorenzi; Matos, 2002).

\section{Extrato etanólico de Punica granatum (EEPg)}

O pericarpo do fruto $(2,5 \mathrm{~kg})$ foi seco em estufa, triturado e colocado em béqueres, por 72 horas com etanol absoluto $97^{\circ} \mathrm{GL}$. Após esse período, o líquido foi filtrado e colocado em pequeno baláo e levado ao rotaevaporador. Sob pressão reduzida e temperatura de $50^{\circ} \mathrm{C}$ houve a separaçáo do extrato e o etanol. O solvente recuperado foi novamente adicionado às mesmas partes das plantas trituradas e submetido à maceração por mais 24 horas, sendo, em seguida, filtrado e evaporado, como descrito anteriormente. 
Esse procedimento foi repetido novamente, por mais duas vezes, num total de três extrações. Os extratos obtidos foram reunidos formando o extrato hidroalcoólico. Posteriormente, o extrato puro foi diluído em várias concentraçôes em soluçấo fisiológica esterilizada para teste de toxicidade.

\section{Coleta dos zigotos murinos}

Foram utilizados 120 camundongos Swiss, púberes, nulíparas, com aproximadamente 8 semanas de idade. Após $48 \mathrm{~h}$ da superovulaçáo ovariana das fêmeas com $0,2 \mathrm{~mL}$ (5 UI) de Gonadotrofina Coriônica Equina (eCG), as fêmeas receberam, também intraperitonealmente, $0,2 \mathrm{~mL}$ (5 UI) de Gonadotrofina coriônica humana (hCG) sendo, entâo, colocadas 2 fêmeas por macho para acasalamento. Após $18 \mathrm{~h}$ da aplicaçấo do hCG para a coleta dos zigotos foi realizada a eutanásia em câmara de $\mathrm{CO}_{2}(\mathrm{CETEA}-\mathrm{IB}$ $\mathrm{n}^{\circ}$ 088/09). Os zigotos foram lavados com TCM199 para remoção das células do cúmulos (Hogan et al., 1986) e separados em quatro grupos para as análises: $\mathrm{G}_{1}$ (zigotos não expostos aos vírus; controle), $\mathrm{G}_{2}$ (zigotos expostos a $10 \mu \mathrm{L}$ de BoHV-1 Colorado a $10^{8} / \mathrm{mL} \mathrm{TCID}_{50} / \mathrm{mL}$ ), $\mathrm{G}_{3}$ (grupo exposto a $10 \mu \mathrm{L}$ de EEPg a $0,001 \%$ em solução salina esterilizada) grupo $\mathrm{G}_{4}$ (expostos a $10 \mu \mathrm{L}$ de BoHV-1 Colorado a $10^{8} / \mathrm{mL} \mathrm{TCID}_{50} / \mathrm{mL}$ e a $10 \mu \mathrm{L}$ de EEPg a 0,001\% em solução salina esterilizada). Foram usados como parâmetros para as análises: aspectos morfológicos, taxa de clivagem, presença das partículas virais pela n-PCR e ECP dos zigotos em cocultura com células MDBK após $72 \mathrm{~h}$.

\section{Aspectos morfológicos}

Foram analisadas as alteraçôes morfológicas nos blastômeros e zona pelúcida dos embriôes após $24 \mathrm{~h}$ por microscópio óptico invertido (Galuppo, 2005).

\section{Taxa de clivagem}

Foi obtida pelo número de zigotos clivados pelo número de total de zigotos após $24 \mathrm{~h}$. Foi utilizado o teste exato de Fisher para verificar a significância entre os grupos $(\alpha=0,05)$ (D`Angelo, 1998).

\section{Cocultivo dos zigotos em MDBK}

Os embriôes foram colocados em cocultivo com células MDBK para a análise da viabilidade viral, pelo ECP e titulação (REED; MUENCH, 1938), após 72 h. Foi utilizado o teste de Mann Whitney para verificar a significância entre os grupos $(\alpha=0,05)$ (PalazZi, 2010).

\section{Extração do DNA}

Para cada $75 \mu \mathrm{L}$ de amostra de lavado de embriáo de todos os grupos, foram adicionados $225 \mu \mathrm{L}$ de Trizol LS Reagent ${ }^{\circ}$
(Invitrogen), agitados em vórtex por $15 \mathrm{~s}$, incubados a $30^{\circ} \mathrm{C}$ durante $5 \mathrm{~min}$. Foram adicionados $60 \mu \mathrm{L}$ de clorofórmio $\left(\right.$ Merck $\left.^{\circledR}\right)$, homogeneizados e novamente incubadas à temperatura de $30^{\circ} \mathrm{C}$ por $5 \mathrm{~min}$. A mistura foi centrifugada a $12.000 \times \mathrm{g} \mathrm{a} 4^{\circ} \mathrm{C}$, por $15 \mathrm{~min}$. Descartou-se o sobrenadante e adicionaram-se $90 \mu \mathrm{L}$ de etanol 100\% (ETOH 100\%), por $3 \mathrm{~min}$. Foram centrifugados novamente ( 5 min a $5.000 \mathrm{xg}$ ). Em seguida o pellet foi lavado com $300 \mathrm{~mL}$ citrato de sódio em $10 \%$ de etanol e incubado por 15 min sob agitaçáo constante. O sobrenadante foi descartado e o pellet lavado com $300 \mu \mathrm{L}$ de etanol $75 \%$ e incubado por 10 min sob agitaçáo constante $(850 \mathrm{rpm})$ em temperatura ambiente e centrifugados por 5 minutos a $5.000 \mathrm{x}$ g. Esse passo foi repetido e depois do descarte do sobrenadante acrescentou-se $45 \mu \mathrm{L}$ de $\mathrm{NaOH}$ para a ressuspensão do pellet. Os tubos foram centrifugados por $5 \mathrm{~min}$ a $12.000 \mathrm{x} \mathrm{g} \mathrm{a} 4^{\circ} \mathrm{C}$. Transferiram-se para um novo tubo $30 \mu \mathrm{L}$ do sobrenadante e acrescentaram-se 7,5 $\mu \mathrm{L}$ de uma solução tampão (HEPES). As amostras de DNA extraídas foram estocadas a $-70^{\circ} \mathrm{C}$ até a etapa de amplificação.

\section{Iniciadores, PCR e n-PCR}

A identificação do BoHV-1 foi realizada utilizando primers específicos desenhados a partir da regiáo da glicoproteína I. Foi usado o kit comercial PCR Master Mix (PROMEGA) para PCR e n-PCR (WhitbeCK et al., 1988). O volume total foi de $25 \mu \mathrm{L}$, contendo PCR Master Mix 1X $(50 \mathrm{u} / \mathrm{mL}$ Taq DNA Polymerase; $400 \mu \mathrm{M}$ de cada DNTP e 3,0 mM $\left.\mathrm{MgCl}_{2}\right), 0,5 \mu \mathrm{M}$ de cada primer e $5 \mu \mathrm{L}$ de DNA. Para a reação de n-PCR, obteve-se volume total de $25 \mu \mathrm{L}$ contendo PCR Master Mix (50u/mL Taq DNA Polymerase; $400 \mu \mathrm{M}$ de cada DNTP e 3,0 $\mathrm{mM} \mathrm{MgCl}$ ), 0,5 $\mu \mathrm{M}$ de cada primer e $2 \mu \mathrm{L}$ de DNA já amplificado.

Cada amplificação foi analisada em gel de agarose a 2\%, preparado em tampão TAE $1 \mathrm{X}$ e submetido à eletroforese. O tamanho dos fragmentos de DNA foi comparado com um padrão de peso molecular apresentando incrementos de $100 \mathrm{pb}$ (DNA ladder de $100 \mathrm{pb}-$ Fermentas $^{\circ}$ ). O tamanho esperado do produto do $\mathrm{PCR}$ é de $468 \mathrm{bp}$, porém a reaçấo de n-PCR produz um produto de $344 \mathrm{bp}$.

\section{Microscopia eletrônica}

Para a MET, após o período de 24 h, os zigotos murinos foram lavados em PBS e fixados por 1 hora em glutaraldeído 2,5\% em tampão PBS 0,1 M e pH 7,4. Foram emblocados em agarose $2 \%$ (blocos de aproximadamente $2 \mathrm{~mm}^{2}$ ) e preparados para serem cortados. Foram realizadas 3 lavagens de 15 min em tampão PBS seguida por pós-fixação em tetróxido de ósmio 1\% em PBS durante 1 h e 3 lavagens de 15 min em água destilada. Imersão de $1 \mathrm{~h} \mathrm{em}$ uranila a 0,5\% em água destilada e novamente 3 lavagens de 15 min em água. Em seguida, para desidratação, 15 min de lavagem em acetona $50 \%$, depois 15 min em acetona $70 \%$, mais 15 min 
em acetona $90 \%$ e finalmente 2 banhos de 10 min seguidos por um último de $15 \mathrm{~min}$ em acetona $100 \%$. Os zigotos murinos foram colocados na resina Spurr e após $72 \mathrm{~h}$ foram cortados com o ultramicrótomo em corte semifino $(2 \mu \mathrm{m})$. Essas secçóes semifinas foram coradas com azul de toluidina a $2 \%$ em soluçáo de borato de sódio $1 \%$ em água destilada. Para análise ultraestrutural os blocos foram seccionados e os cortes ultrafinos recolhidos em telas de níquel. As telas foram lavadas em BSA com Tween 20 em PBS, pH 7,0, incubadas em cloreto de amônio $5 \mathrm{Mm}$ (para bloquear e evitar a ligação específica de anticorpos em grupamento aldeídico livre presente nas células fixadas) e lavadas em BSA com Tween 20 em PBS, pH 7,0. A seguir as telas foram incubadas com anticorpo primário 1:80 em PBS/BSA 1\% por 4 h, lavadas em BSA com Tween 20 em PBS, pH 7,0, incubadas com anticorpo secundário (proteína A-ouro) 1:10 em PBS/ BSA 1\%, lavadas em PBS, pH 7,0 e fixadas com glutaraldeído 2,5\% em água. Após lavagem em água as telas foram contrastadas com acetato de uranila e citrato de chumbo. No início e final do processamento as telas foram tratadas com metaperiodato de sódio (solução saturada) (KNUTTON, 1995; PADRón, 1998 apud ATHAYDE, 2007). As telas foram gravadas com auxílio do microscópio eletrônico de transmissão JEOL JEM 1010 no Instituto de Ciências Biomédicas/Universidade de São Paulo. Verificamos a morfologia dos zigotos/embrióes murinos (Zona Pelúcida membrana plasmática, organelas e carioteca) e a presença das partículas virais após tratamento com EEPg.

\section{Toxicidade do extrato etanólico da Punica granatum em células MDBK e em embriões murinos}

Inicialmente foram realizados testes de toxicidade do EEPg em células MDBK com a finalidade de encontrar um parâmetro (ampla sintonia) para os testes definitivos de toxicidade em zigotos. O EEPg foi diluído em solução fisiológica esterilizada nas seguintes concentraçôes: $20 ; 15 ; 10 ; 5 ; 4 ; 3 ; 2 ; 1 ; 10^{-1}$; $10^{-2} ; 10^{-3} ; 10^{-4} ; 10^{-5} ; 10^{-6}$ e $10^{-7} \%$. Um volume de $10 \mu \mathrm{L}$ de cada uma das concentraçóes foi adicionado às células MDBK cultivadas em placas de 96 poços em estufa, durante $24 \mathrm{~h}$, a $37^{\circ} \mathrm{C}$ e $5 \%$ de $\mathrm{CO} 2$, sendo que cada poço continha $110 \mu \mathrm{L}$ de meio de cultura TCM 199. Ao final, cada poço continha $120 \mu \mathrm{L}$ (meio de cultura + extrato). Posteriormente, repetimos o teste com zigotos, no entanto, com concentraçóes do $\mathrm{EEPg}$ próximas à concentração não tóxica para células $\mathrm{MDBK}$.

\section{Teste do extrato etanólico da Punica granatum em embriões murinos infectados experimentalmente por BoHV-1}

Os zigotos coletados, mantidos em gotas de meio TCM 199 suplementado com $10 \%$ de soro bovino fetal (SBF) livre do vírus da diarreia viral bovina (BVDV) e BoHV-1 e 0,2\% de piruvato de sódio, sob óleo mineral esterilizado, foram divididos nos seguintes grupos: controle $\left(\mathrm{G}_{1}\right.$; com $100 \mu \mathrm{L}$ de meio TCM199 + 10\% de SFB + $20 \mu \mathrm{L}$ de solução fisiológica esterilizada), expostos aos vírus $\left(\mathrm{G}_{2}\right.$; com $100 \mu \mathrm{L}$ de meio TCM199 + 10\% de SFB + $10 \mu \mathrm{L}$ da suspensão de vírus com título de $10^{8} \mathrm{TCID}_{50} / \mathrm{mL}+10 \mu \mathrm{L}$ de solução fisiológica esterilizada); expostos ao EEPg $\left(\mathrm{G}_{3}\right.$ : com $100 \mu \mathrm{L}$ de meio TCM $199+10 \%$ de SFB + $10 \mu \mathrm{L}$ de EEPg a 0,001\% + $10 \mu \mathrm{L}$ de solução fisiológica esterilizada); expostos aos vírus e ao $\operatorname{EEPg}\left(\mathrm{G}_{4}\right.$; com $100 \mu \mathrm{L}$ de meio TCM $199+10 \%$ de SFB $+10 \mu \mathrm{L}$ de EEPg a 0,001\% + $10 \mu \mathrm{L}$ da suspensão de vírus com título de $\left.10^{8} \mathrm{TCID}_{50} / \mathrm{mL}\right)$.

As culturas foram mantidas em estufa a $5 \%$ de $\mathrm{CO}_{2}, 90 \%$ de umidade e $37^{\circ} \mathrm{C}$. Após 24 h de contaminação os zigotos foram separados em subgrupos para avaliação da morfologia, taxa de clivagem, cocultivo em MDBK e ME.

Este trabalho foi realizado conforme os princípios éticos da experimentação animal estabelecidos pela Comissão de Ética na Experimentação Animal (CETEA-IB) conforme consta em declaraçấo de 27/11/13, sob o protocolo no $124 / 12$.

\section{RESULTADOS}

Os grupos $G_{1}, G_{3}$ e $G_{4}$ (grupos teste) não apresentaram embrióes com alteraçóes morfológicas após 24, 48 e $96 \mathrm{~h}$ (Figs. 1, 3 a 5). O grupo $\mathrm{G}_{2}$ apresentou alteraçôes morfológicas, como falha na divisão e aumento do espaço periplasmático (Fig. 2). Após $24 \mathrm{~h}$, foram constatadas as seguintes taxas de clivagens: $\mathrm{G}_{1}$ igual a $76 \%(254 / 336) ; \mathrm{G}_{2}$ igual a $63 \%(234 / 370) ; \mathrm{G}_{3}$ igual a $72 \%(75 / 104)$ e $\mathrm{G}_{4}$ igual a $75 \%$ $(206 / 274)$. Não foi constatada diferença significativa $(p<0,05)$ com relação à taxa de clivagem entre os grupos $G_{1} \times G_{2} ; G_{1} x$ $\mathrm{G}_{3}$ e $\mathrm{G}_{1} \times \mathrm{G}_{4}$. As médias relacionadas a quatro titulaçóes da cocultura dos embrióes em células $\operatorname{MDBK}\left(\mathrm{G}_{2}=10^{7} \mathrm{TCID}_{50} /\right.$ $\mathrm{mL} \mathrm{e}_{4}=10^{2} \mathrm{TCID}_{50} / \mathrm{mL}$ ) apresentaram diferença significativa $(p<0,05)$. A incubação dos embrióes do grupo $G_{4}$ tratados com EEPg em células MDBK apresentaram ECP discreto (Fig. 7), que é compatível com diminuição das partículas virais constatada pela titulaçáo viral após $72 \mathrm{~h}$. Segundo a n-PCR, os grupos $G_{1}$ e $G_{3}$ apresentaram resultados negativos, enquanto $G_{2}$ e $G_{4}$, positivos (Fig. 8). Após análise da $M E$, foi possível verificar a conservação das principais estruturas celulares (zona pelúcida, membrana plasmática, mitocôndria e carioteca) dos embriōes do grupo teste $\left(\mathrm{G}_{4}\right)$ (Figs. 13 a 15), apesar do abaulamento da membrana plasmática (Fig. 15). Não foi possível a detecção das partículas virais no grupo $G_{4}$, somente no grupo $\mathrm{G}_{2}$ (Fig. 12). A perturbação da membrana plasmática também foi detectada no grupo $G_{2}$ (Fig. 10). As Figuras 9 e 11 demonstram as "estruturas" conservadas do grupo controle $\left(\mathrm{G}_{1}\right)$. 


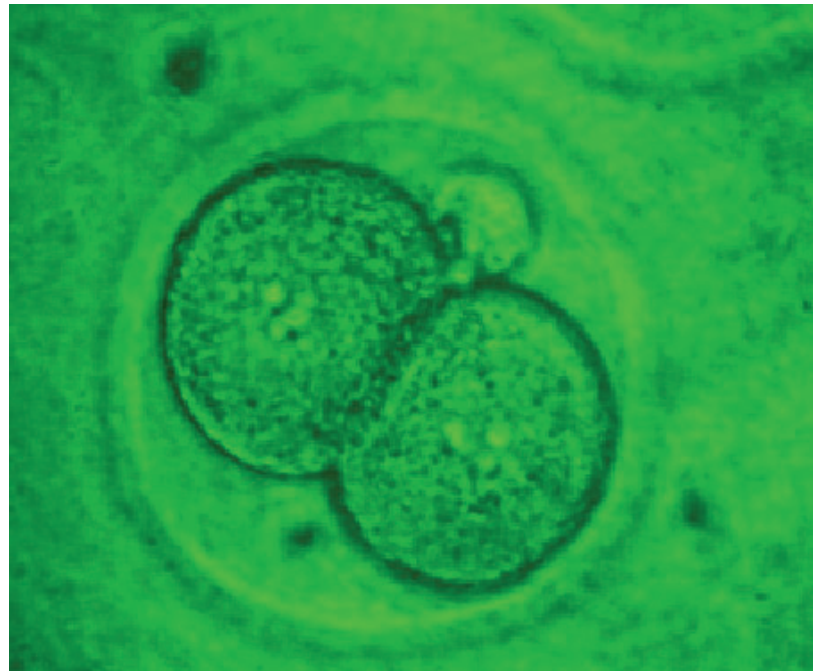

Figura 1. Embrião do grupo $G_{1}$ (controle) sem alterações morfológicas após $24 \mathrm{~h}$ de incubação. É possível verificar a zona pelúcida íntegra e o corpúsculo polar (100x, 5,7x zoom).

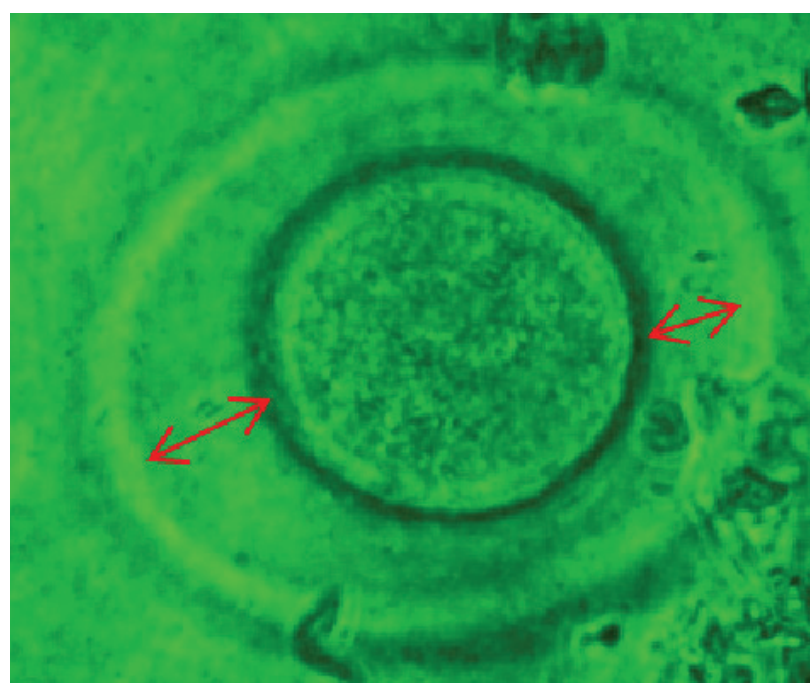

Figura 2. Embrião exposto aos vírus $\left(\right.$ Grupo $G_{2}$ ) sem clivagem após $24 \mathrm{~h}$ de incubação. Aumento do espaço periplasmático (seta em vermelho) (100x, 5,7x zoom).

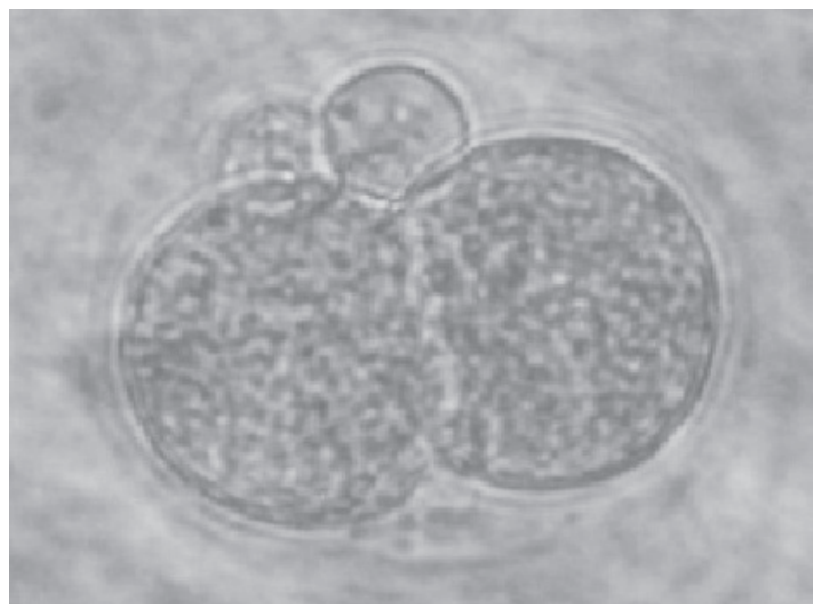

Figura 3. Embrião exposto aos ao extrato etanólico da casca de Punica granatum_( $\left.\mathrm{G}_{3}\right)$, blastômeros simétricos, com citoplasma uniforme após $24 \mathrm{~h}$ de incubação. Presença dos dois corpúsculos polares na região apical da foto (100x, 5,7x zoom).

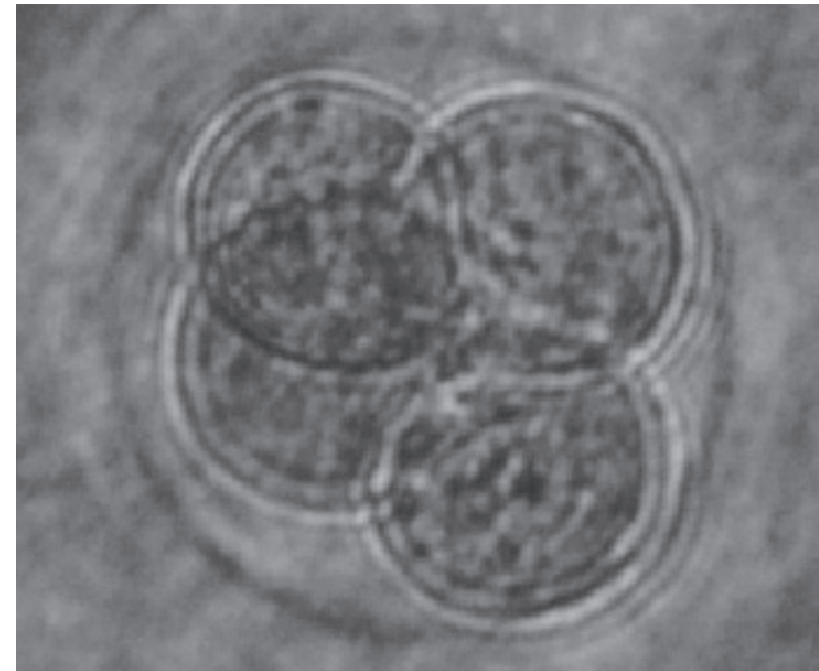

Figura 4. Embrião exposto aos vírus e ao extrato etanólico da casca de Punica granatum (Grupo $\mathrm{G}_{4}$ ) após $48 \mathrm{~h}$ de incubação. Com duas clivagens e quatro células (100x, 5,7x zoom).

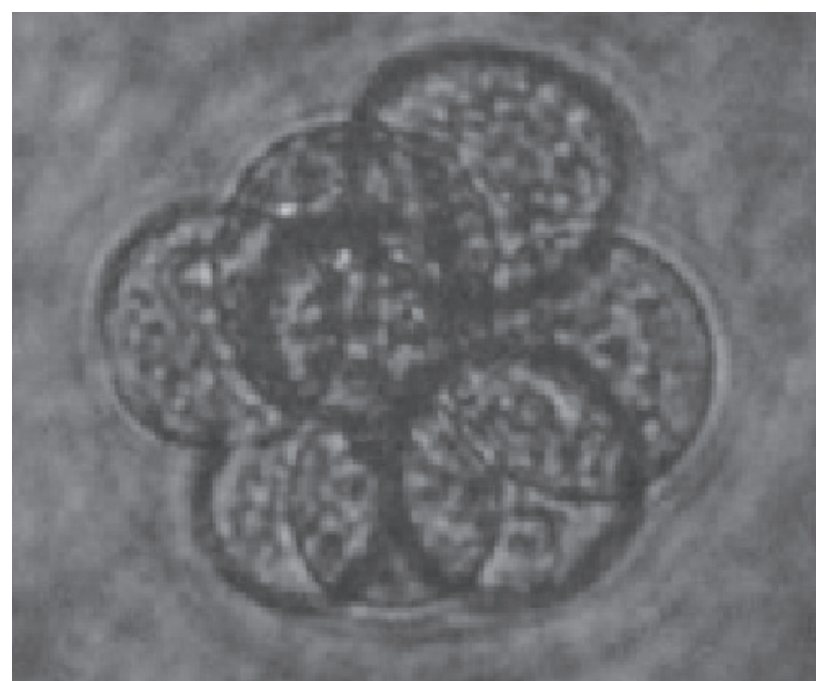

Figura 5. Embrião exposto aos vírus e ao extrato etanólico da casca de Punica granatum_(Grupo $\mathrm{G}_{4}$ ) após $72 \mathrm{~h}$ de incubação. Com três clivagens e oito células (100x, 5,7x zoom).

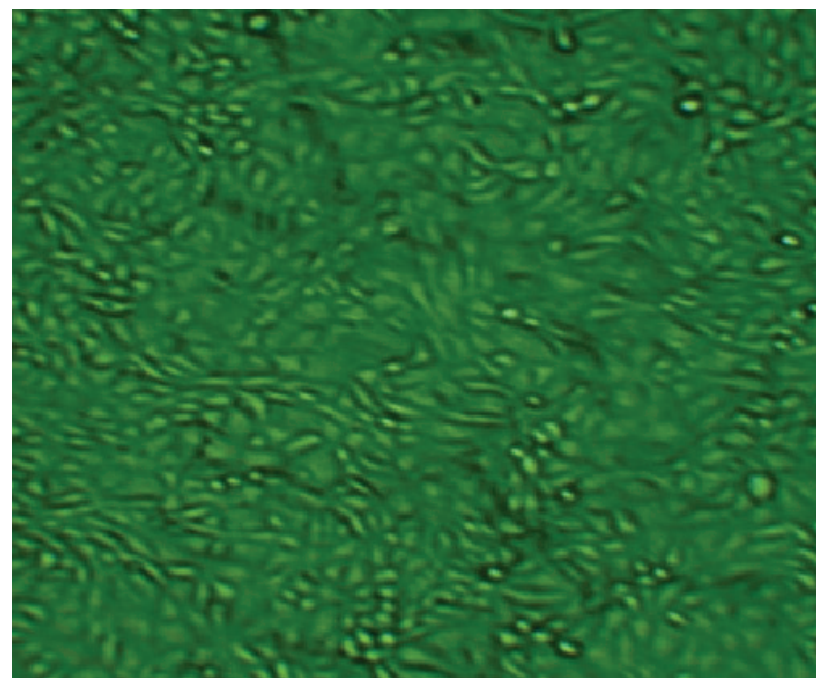

Figura 6. Monocamadas de células MDBK em cultura com TCM 199 acrescentado em $10 \%$ de soro bovino fetal (100x, 4x zoom). 


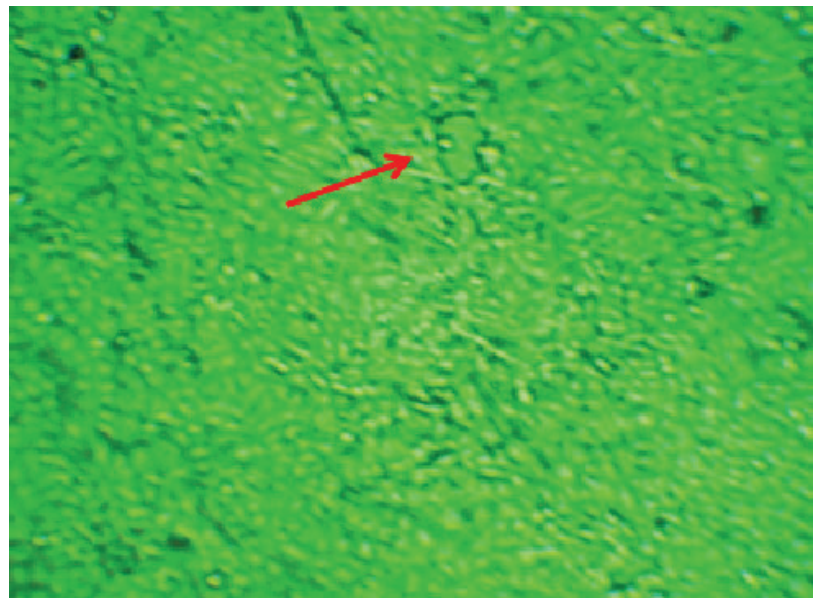

Figura 7. Cultura MDBK inoculadas com embrião do grupo $\mathrm{G}_{4}$ (Punica granatum) com "discreto efeito citopático" (seta) (100x, 4,1x zoom)

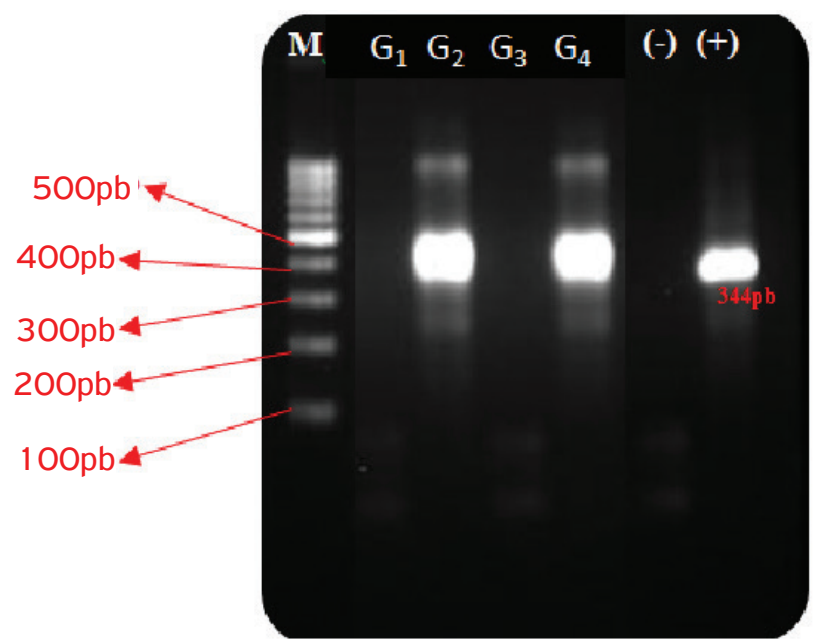

Figura 8. Nested PCR. M: padrão de peso molecular DNA ladder de $100 \mathrm{pb} ; \mathrm{G}_{1}$ : controle; $\mathrm{G}_{2}$ : exposto aos vírus; $\mathrm{G}_{3}$ : exposto ao extrato etanólico da casca de Punica granatum; $\mathrm{G}_{4}$ : exposto aos vírus e ao extrato etanólico da casca de Punica granatum; (-): controle negativo; $(+)$ : controle positivo.

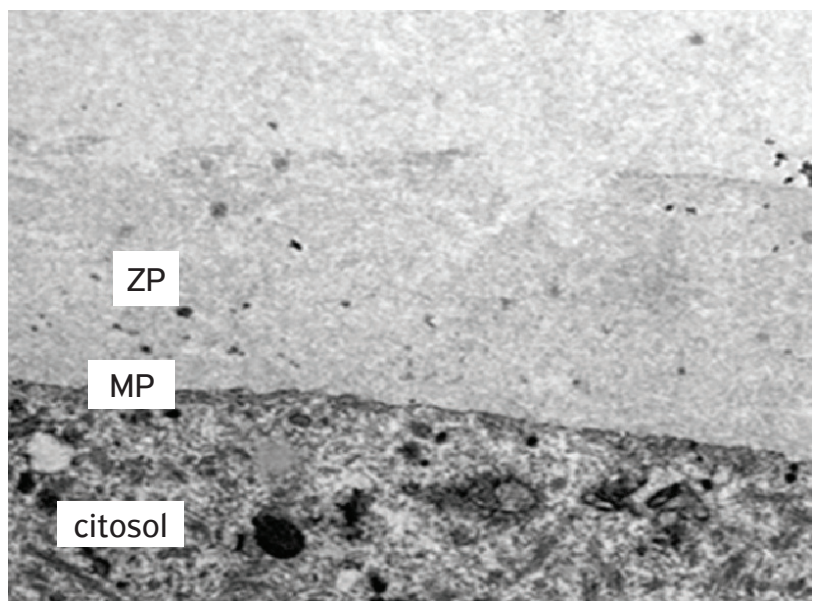

Figura 9. Embrião do grupo controle (Grupo G1). ZP: zona pelúcida; MP: membrana plasmática. Todas estruturas conservadas. Aumento: 7.500x.

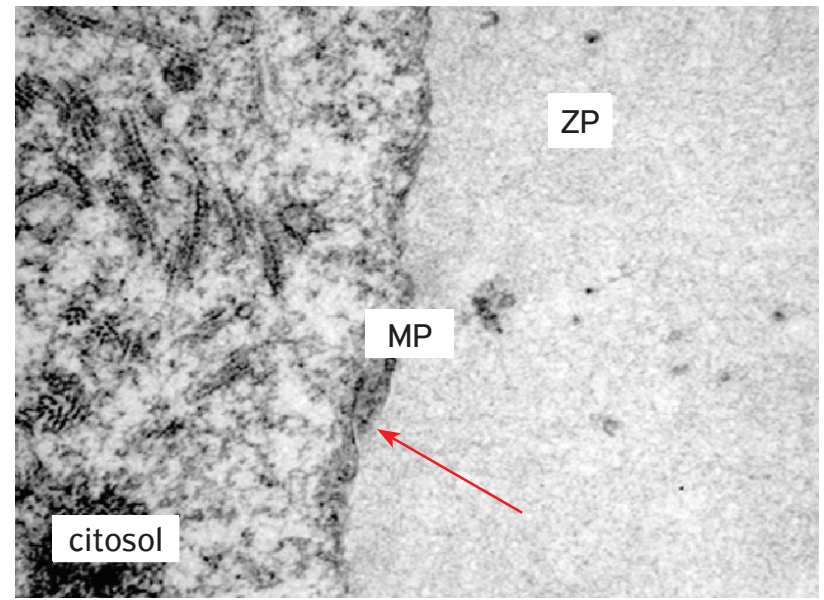

Figura 10. Embrião exposto aos vírus (Grupo $G_{2}$ ). ZP: zona pelúcida; MP: membrana plasmática. Note (seta) perturbação da membrana plasmática. Aumento: 30.000x.

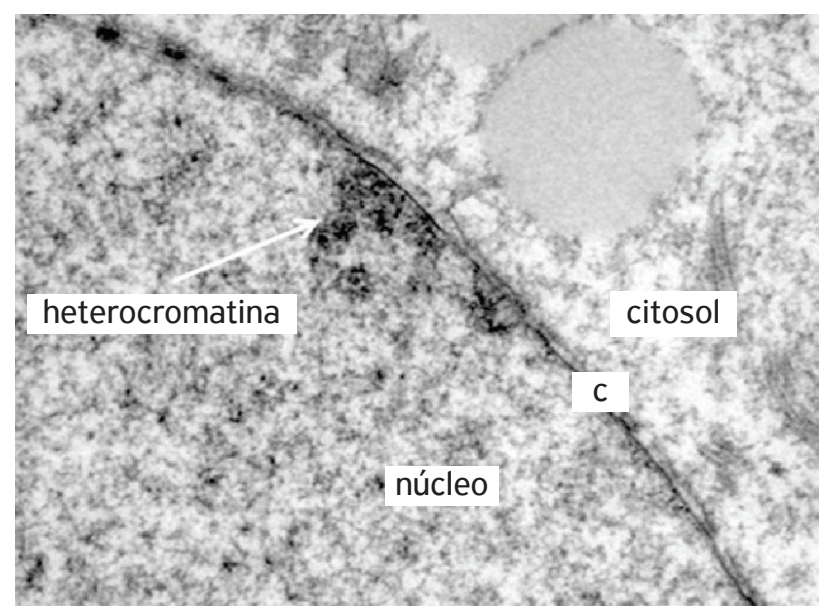

Figura 11. Embrião do grupo controle G1. Em destaque hetreocromatina (seta); C: carioteca íntegra. Aumento: 30.000x.

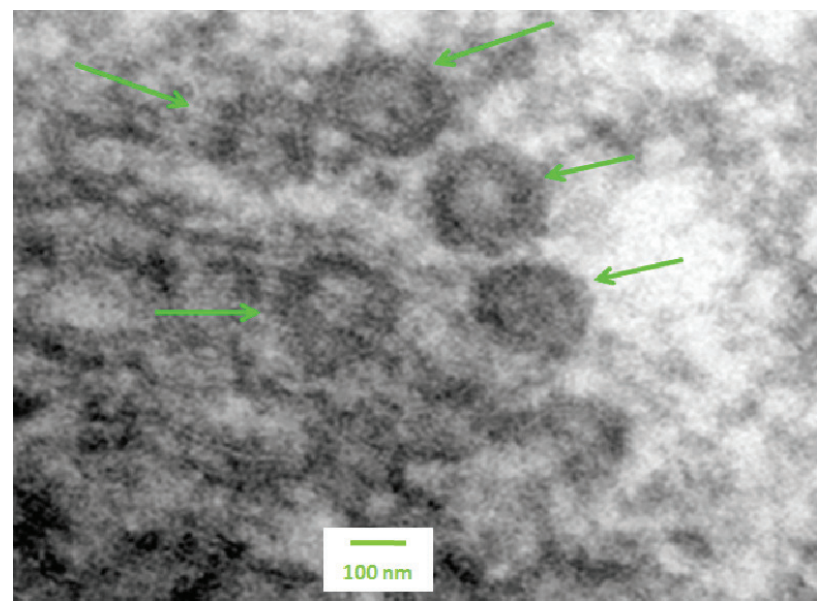

Figura 12. Embrião exposto aos vírus (Grupo $G_{2}$ ). Destaque para as partículas virais (setas verdes) encontradas no citosol. Aumento: $120.000 x$. 


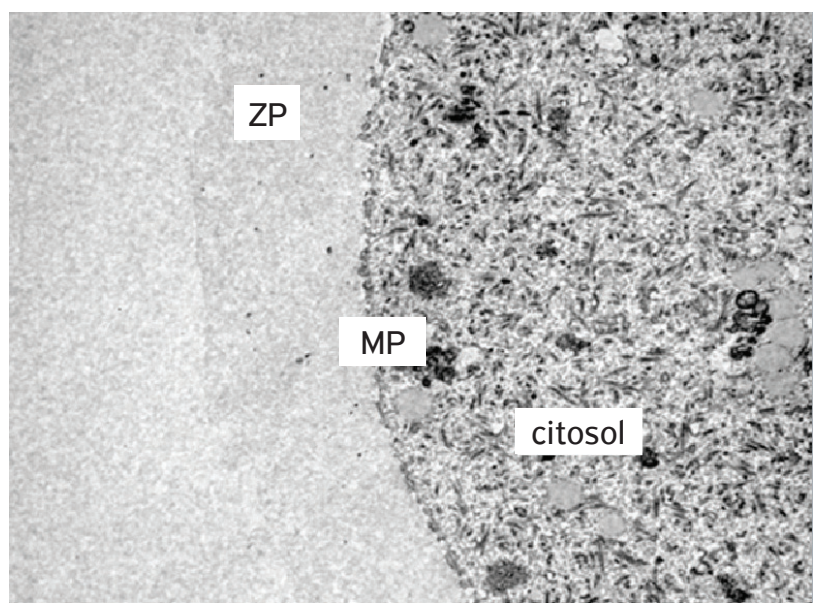

Figura 13. Embrião exposto aos vírus e ao extrato etanólico da casca de Punica granatum (Grupo $\mathrm{G}_{4}$ ). ZP: zona pelúcida; MP: membrana plasmática. Todas estruturas conservadas. Aumento: 4.000x.

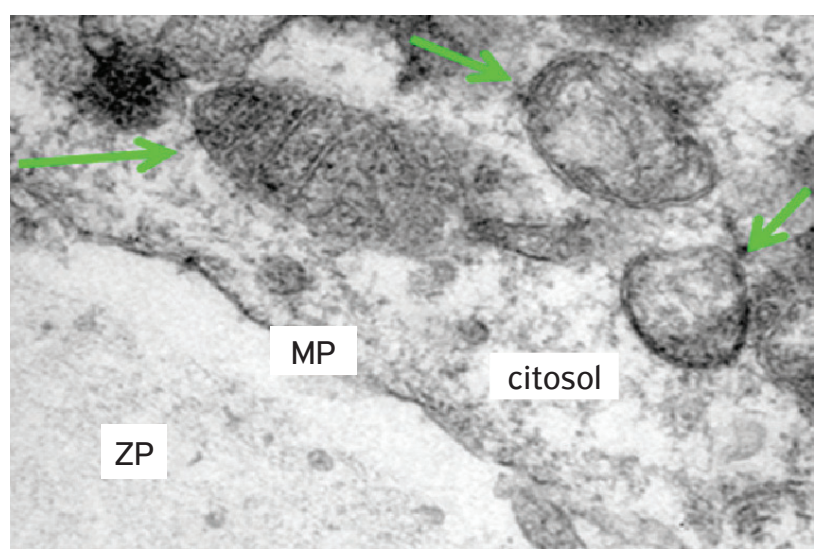

Figura 14. Embrião exposto aos vírus e ao ao extrato etanólico da casca de Punica granatum (Grupo $\mathrm{G}_{4}$ ). ZP: zona pelúcida; MP: membrana plasmática. Setas verdes: mitocôndrias. Todas as estruturas conservadas. Aumento: 20.000x.

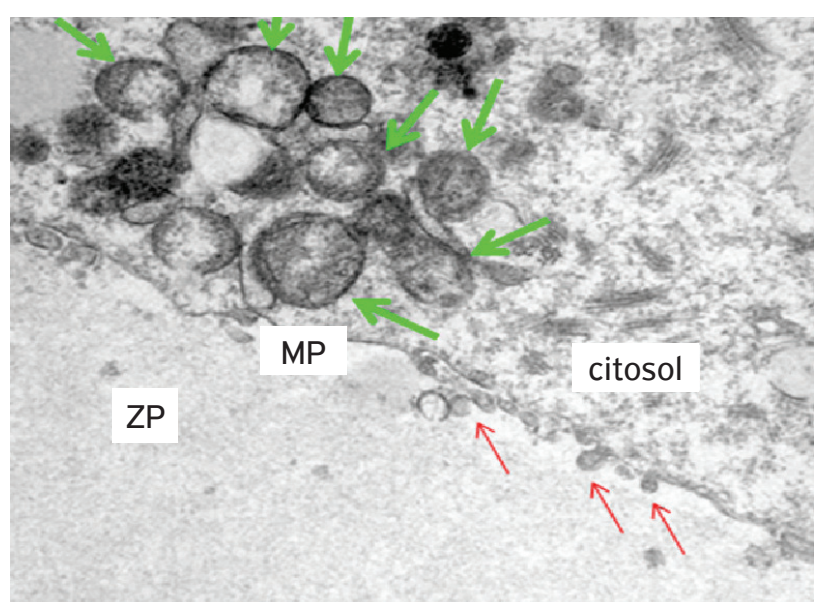

Figura 15. Embrião exposto aos vírus e ao ao extrato etanólico da casca de Punica granatum (Grupo $\mathrm{G}_{4}$ ). ZP: zona pelúcida; MP: membrana plasmática. Setas vermelhas: perturbação da membrana plasmática, porém, sem rompimento. Setas verdes: mitocôndrias preservadas. Aumento: 20.000x.

\section{DISCUSSÃO}

A produçáo in vitro (PIV) tem sido difundida em diversos países e de forma destacada no Brasil a partir da década de 1990, sendo que hoje o Brasil é reconhecido internacionalmente pela técnica de Fertilização in vitro. Paradoxalmente, a biotecnologia da reprodução, que permite maior controle das células reprodutivas, pode ao mesmo tempo ser disseminadora de patógenos com maior rapidez e fornecer prejuízos consideráveis em escala mundial (STRINGFELlow et al., 2004; Palazzi et al., 2012). Justifica-se, portanto, a pesquisa em busca de novos meios de controle sanitário através de agentes antivirais com possível ação intra e extracelular.

Para os testes com antivirais, foram escolhidos embrióes murinos, pois se apresentam como um modelo de alta confiabilidade segundo inúmeros trabalhos (MALLEK et al., 1984; NaGy et al., 2003; Palazzi et al., 2009; PALazZI, 2010) além de serem sensíveis ao BoHV-1, de fácil acesso e baixo custo (Galuppo, 2002).

Zhang et al. (1995) verificaram que o extrato da casca de Púnica granatum mostrou ação contra o Herpes simplex vírus humano 1 e 2 in vitro. JADHAV et al. (2012) pesquisaram inúmeras plantas, como Azadirachta indica, Curcuma longa (açafrão da família do gengibre), Punica granatum (romã), Ocimum sanctum, Nyctanthes arbortristis, Carica papaya (mamão) e Holarrhena antidysentrica. Todas provenientes de Gujarat, estado da Índia. Foram obtidos 24 extratos, sendo que apenas 5 indicaram ação contra o herpesvírus. Segundo a pesquisa, o pó liofilizado de Punica grantum exibiu atividade antiviral promissora. Porém, não existe nenhuma pesquisa com foco em células reprodutivas proveniente da PIV.

Dados de nossa pesquisa indicam também que o extrato etanólico do pericarpo de Punica granatum mostrou açấo contra o herpesvírus bovino tipo 1 ao reduzir a replicação viral. Não houve bloqueio total, pois o resultado da n-PCR acusou a presença da partícula viral nos grupos testes, $G_{4}$ (Fig. 8), e foi detectado ECP em células MDBK (Fig. 7), no entanto, de forma moderada. Provavelmente encontramos todos os embriōes dos grupos que foram submetidos ao BoHV-1 Colorado positivo pela n-PCR devido ao alto título intencionalmente usado $\left(10^{8} \mathrm{TCID}_{50} / \mathrm{mL}\right)$. Segundo StRINGFellow et al. (2004), há a necessidade de que os títulos virais, in vitro, estejam em altas concentraçóes para promover máxima oportunidade de adsorção vírus-células. Mesmo assim, a titulação demonstrou uma queda de partículas virais: a média das 4 titulaçôes do grupo $\mathrm{G}_{2}$ foi de $3,70 \times 10^{7} \mathrm{TCID}_{50} / \mathrm{mL}$, enquanto a do grupo $G_{4}$ foi de $6,51 \times 10^{2}$, demonstrando diferença significativa entre os grupos $G_{2}$ e $G_{4}$, segundo teste estatístico Mann-Whitney $(\mathrm{p}=0,02 ; \alpha=5 \%)$. Outro fator importante é que não encontramos diferença significativa na taxa de clivagem relativa aos grupos $\mathrm{G}_{1}$ (controle) e $\mathrm{G}_{4}$ (teste) segundo teste exato de Fisher $(\mathrm{p}=0,92 ; \alpha=5 \%)$. Resultados favoráveis, também, foram observados em relaçáo à morfologia por microscopia óptica, 
onde náo observamos alteraçóes morfológicas no grupo teste, $\mathrm{G}_{4}$ (Figs. 4 e 5), quando comparado ao grupo controle, $\mathrm{G}_{1}$ (Fig. 1), e grupo exposto aos vírus, G2 (Fig. 2).

Os resultados de MET demonstraram que todos os embrióes murinos que passaram pelos tratamentos com extratos não romperam a zona pelúcida $(\mathrm{ZP})$ e mantiveram suas estruturas conservadas (Figs. 9 a 11, 13 a 15). Foi possível encontrar somente partículas virais por MET no grupo $\mathrm{G}_{2}$ (Fig. 12), o que não significa que não havia vírus no grupo $\mathrm{G}_{4}$, conforme resultados de cocultivo e titulação que demonstraram presença de vírus viável, apesar de também indicarem a redução da taxa viral do BoHV-1. Os embrióes expostos aos vírus apresentaram "pertubaçóes" na membrana plasmática (MP), provavelmente pela açáo viral (Figs. 14 e 15). Essa deformaçáo presente na MP dos embrióes murinos pode estar relacionada à liberação das partículas virais por exocitose (WILD et al., 2002) ou por interferir em mecanismos relacionados ao equilíbrio da MP e da célula, como a proteína quinase dependente de cálcio (CaMK), que é um importante sinalizador celular (Mryake; McNeIl, 1995; Silva et al., 2009).

Todos estes dados, analisados em conjunto, refletem a redução das partículas virais pela ação do extrato ao compararmos com o grupo exposto aos vírus e não tratado com EEPg, permitindo, desta forma, o desenvolvimento do embriáo. Cabe destacar que esclarecimentos da(s) molécula(s) envolvidas do EEPg são necessários para potencializar a ação e o entendimento desse efeito com futuros trabalhos. Além disso, salientamos que os experimentos foram realizados in vitro, por isso não contamos, evidentemente, com mecanismos in vivo como disposição tecidual, sistema imunológico, entre outros. Por isso, consideramos sempre que a transposição de sistemas in vitro para in vivo exige cautela (D'ANGELO, 1998).

Mesmo com as últimas ponderaçóes, consideramos que o EEPg demonstra resultados promissores para uso em protocolos de FIV de bovinos por diminuir, significativamente, a replicação viral e, ao mesmo tempo, permitir o pleno desenvolvimento dos embrióes murinos.

\section{AGRADECIMENTOS}

Ao Dr. Ricardo S. Jordão pela essencial ajuda ao ceder espaço e todo suporte no biotério, e ao apoio financeiro imprescindível do Conselho Nacional de Desenvolvimento Científico e Tecnológico (CNPq) do Brasil. REFERÊNCIAS

ATHAYDE, C.S. Interação do parvovírus suíno com oócitos suínos durante o período de maturação in vitro. 2007. 52f. Dissertação (Mestrado em Biotecnologia) - Instituto de Ciências Biomédicas, Universidade de São Paulo, São Paulo, 2007.

CERQUEIRA, R.B.; CARMINATI, R.; SILVA, J.M.; SOARES, G.C.; MEYER, R.; SARDI, S. Serological survey for bovine herpesvirus 1 in cattle from different regions in the state of Bahia, Brazil. Brazilian Journal of Veterinary Research and Animal Science, v.37, n.6, p. 1-8, 2000.

COLODEL, E.M.; NAKAZATO, L.; WEIBLEN, R.; MELLO, R.M.; SILVA, R.R.P.; SOUZA, M.A.; OLIVEIRA FILHO, J.A.; CARON, L. Meningoencefalite necrosante em bovinos causada por herpesvírus bovino no Estado de Mato Grosso, Brasil. Ciência Rural, v.32, n.2, p.293-298, 2002.

D'ANGELO, M. Interação do herpesvirus bovino tipo-1 (BoHV1) com oócitos bovinos maturados in vitro. 1998. 52f. Tese (Doutorado em Microbiologia) - Departamento de Microbiologia do Instituto de Ciências Biomédicas, Universidade de São Paulo, São Paulo, 1998.

GALUPPO, A.G.; D’ANGELO, M.; PIATTI, R.M; BARRA, S.H.C.; GONÇALVES, R.F. Detection of bovine herpesvirus type 1 (BHV1 ) in experiments with in vitro-infected murine zygotes by the Nested-PCR technique. Theriogenology, v.57, p.571, 2002.

GALUPPO, A.G. Avaliação da sensibilidade de zigotos murinos à Brucella abortus para o estabelecimento de um modelo experimental em estudos de interações embriões-patógenos. 2005. $74 \mathrm{f}$. Dissertação (Mestrado em Epidemiologia Experimental e Aplicada à Zoonozes) - Faculdade de Medicina Veterinária e Zootecnia, Universidade de São Paulo, São Paulo, 2005.

HOGAN, B.; CONSTANTINI, F.; LACY, E. Developmental genetics and embryology of the mouse: past, present, and future. In: HOGAN, B.; CONSTANTINI, F.; LACY, E. (Eds.). Manipulating the mouse embryo: a laboratory manual. Cold Spring Harbor: Cold Spring Harbor Laboratory, 1986. p.12-14.

JADHAV, P.; KAPOOR, N.; THOMAS, B.; LAL, H.; KSHIRSAGAR, N. Antiviral potential of selected Indian medicinal (ayurvedic) plants against herpes simplex virus 1 and 2. North American Journal of Medical Sciences, v.4, n. 12, p.641-647, 2012.

KNUTTON, S. Electron microscopical methods in adhesion. Methods in Enzymology, v.253, p.145-158, 1995.

KUNRATH, C.F.; VOGEL, F.S.F.; OLDONI, I.; FLORES, E.F.; WEIBLEN, R.; DEZENGRINI, R.; TORRES, F.D.; PAN, K.A. Soroneutralização e imunofluorescência utilizando anticorpos monoclonais no diagnóstico rápido de infecções pelo herpesvírus bovino tipos 1 e 5 (BHV-1 e BHV-5). Ciência Rural, v.34, n.6, p.18771883, 2004.

LORENZI, H.; MATOS, F.J.A. Punica granatum L. In: LORENZI, H.; MATOS, F.J.A. Plantas medicinais no Brasil: nativas e exóticas. Nova Odessa: Instituto Plantarum de Estudo da Flora Ltda, 2002. p.394-395. 
MALLEK, Z.; GUERIN, B.; NIBART, M.; PAREZ, M.; THIBIER, M. Conséquences de la contamination in vitro des embryons de souris et de vaches par B. abortus. Bulletin de l'Académie Veterinari de France, v.57, p.479-490, 1984.

MIYAKE, K.; MCNEIL, P.L. Vesicle accumulation and exocytosis at sites of plasma membrane disruption. Journal of Cell Biology, v.131, n.6, pt.2, p. 1737-1745, 1995.

NAGY A, GERTSENSTEIN M, VINTERSTEN K, BEHRINGER R. Manipulating the mouse embryo: a laboratory manual. New York: 3th Ed Cold Spring Harbor Laboratory Press, 2003. p.25 1-273.

PALAZZI, E.G.; GOES, A.C; PICCOLOMINI, M.M.; PAVÃO, D.L.; BATISTA, M.L.; ALVES, M.F.; D’ANGELO, M. Avaliação da taxa de clivagem em zigotos murinos infectados, experimentalmente, com o vírus da Rinotraqueíte Infecciosa Bovina (BoHV-1), amostra Colorado. SBM in Foco, n.9, p.132, 2009.

PALAZZI, E.G; GONÇALVES, F.R.; HANSEN, D.; FELICIO, J.D.; ALMEIDA, M.L.; ALVES, M.F.; NOGUEIRA, A.H.C.; STURARO, L.G.R.; PITUCO, E.M.; PAVÃO, D.L.; D’ANGELO, M. Evaluation of Pomegranate (Punica granatum) as replication inhibitor of BoHV-1 Colorado strain of experimentally infected murine zygotes. In: XXIII BRAZILIAN CONGRESS OF VIROLOGY \& VII MERCOSUR MEETING OF VIROLOGY, v. 17, n. 2, 2012, Foz do Iguaçu. Foz do Iguaçu: 2012 . p.394.

PALAZZI, E.G. Efetividade da tripsina sobre embriões murinos infectados experimentalmente com BoHV-1.2010.77f. Dissertação (Mestrado em Biotecnologia) - Instituto de Ciências Biomédicas, Universidade de São Paulo, São Paulo, 2010.

REED, L.J.; MUENCH, H. A simple method of estimating fifty per cent endpoints. American Journal of Hygiene, v.27, n.3, p.493497, 1938.

SILVA, B.V.; HORTA, B.A.C.; ALECASTRO, R.B.; PINTO, A.C. Proteínas quinases: características estruturais e inibidores químicos. Química Nova, v.32, n.2, p.453-462, 2009. Disponível em: <http://www.scielo.br/scielo.php?script=sci_arttext\&pid=SO100$40422009000200032 \&$ Ing=en\&nrm=iso $>$. Acesso em: 15 fev. 2014.
SOUSA, M.P.; MATOS, F.J.A.; MATOS, M.E.O.; MACHADO, M.I.L.; CRAVEIRO, A.A. Constituintes químicos ativos e propriedades biológicas de plantas medicinais brasileiras. Fortaleza: UFC, 1991.416p.

SINGH, E.L.; THOMAS, F.C.; PAPP-VID, G.; EAGLESOME, M.D.; HARE, W.C. Embryo transfer as a means of controlling the transmission of viral infections II: the in vitro exposure of preimplantation bovine embryos to infectious bovine rhinotracheitis virus. Theriogenology, v.18, n.2, p.133-140, 1982.

STRINGFELLOW, D.A.; LAUERMAN, L.H.; NASTI, K.B.; GALIK, P.K. Trypsin treatment of bovine embryos after in vitro exposure to infectious bovine rhinotacheitis virus or bovine herpes virus- 4 . Theriogenology, v.34, n.3, p.427-434, 1990.

STRINGFELLOW, D.A.; GIVENS, M.D. epidemiologic concerns relative to in vivo and in vitro production of livestock embryos. Animal Reproduction Science, v.60-61, p.629-642, 2000.

STRINGFELLOW, D.A.; GIVENS, M.D.; WALDROP, J.G. Biosecurity issues associated with current and emerging embryo technologies. Reproduction, Fertility and Development, v.16, n.1-2, p.93-102, 2004.

VIEIRA, S.; BRITO, W.M.E.D.; SOUZA, W.J.; ALFAIA, B.T.; LINHARES, D.C.L. Anticorpos para o herpesvírus bovino 1 (BHV-1) em bovinos do Estado de Goiás. Ciência Animal Brasileira, v.4, n.2, p.131-137, 2003.

WILD, P.; SCHRANER, E.M.; CANTIENI, D.; LOEPFE, E.; WALTHER, P.; MÜLLER, M.; ENGELS, M. The significance of the Golgi complex in envelopment of bovine herpesvirus 1 (BHV-1) as revealed by cryobased electron microscopy, Micron, v.33, n.4, p.327$337,2002$.

WHITBECK, J.C.; BELLO, L.J.; LAWRENCE, W.C. Comparison of the bovine herpesvirus $1 \mathrm{gl} \mathrm{gene}$ and the herpes simplex virus type $1 \mathrm{gB}$ gene. Journal of Virology, v.62, n.9, p.3319-3327, 1988.

ZHANG, J.; ZHAN, B.; YAO, X.; GAO, Y.; SHONG J. Antiviral activity of tannin from the pericarp of Punica granatum $\mathrm{L}$. against genital Herpes virus in vitro. Zhongguo Zhong Yao Za Zhi, v.20, n.9, p.556-558, 1995. 